Article

\title{
An Alternative Risk Assessment Model of Urban Waterlogging: A Case Study of Ningbo City
}

\author{
Meiling Zhou ${ }^{1}$, Xiuli Feng ${ }^{1, *}$, Kaikai Liu ${ }^{1}$, Chi Zhang ${ }^{1}$, Lijian Xie ${ }^{1}$ and Xiaohe Wu ${ }^{2, *}$ \\ 1 Institute of Human Geography and Urban-Rural Planning, Faculty of Geography science and Tourism \\ Culture, Ningbo University, Ningbo 315211, China; 1811073023@nbu.edu.cn (M.Z.); \\ 1911073010@nbu.edu.cn (K.L.); personalmail_zc@163.com (C.Z.); xljnbu@163.com (L.X.) \\ 2 Nottingham University Business School, University of Nottingham Ningbo China, Ningbo 315000, China \\ * Correspondence: fengxiuli@nbu.edu.cn (X.F.); Xiaohe.Wu@nottingham.edu.cn (X.W.)
}

Citation: Zhou, M.; Feng, X.; Liu, K.; Zhang, C.; Xie, L.; Wu, X. An

Alternative Risk Assessment Model of Urban Waterlogging: A Case Study of Ningbo City. Sustainability 2021, 13, 826. https://doi.org/10.3390/ su13020826

Received: 12 December 2020

Accepted: 12 January 2021

Published: 15 January 2021

Publisher's Note: MDPI stays neutral with regard to jurisdictional clai$\mathrm{ms}$ in published maps and institutional affiliations.

Copyright: $(\odot 2021$ by the authors. Licensee MDPI, Basel, Switzerland. This article is an open access article distributed under the terms and conditions of the Creative Commons Attribution (CC BY) license (https:// creativecommons.org/licenses/by/ $4.0 /)$.

\begin{abstract}
Influenced by climate change, extreme weather events occur frequently, and bring huge impacts to urban areas, including urban waterlogging. Conducting risk assessments of urban waterlogging is a critical step to diagnose problems, improve infrastructure and achieve sustainable development facing extreme weathers. This study takes Ningbo, a typical coastal city in the Yangtze River Delta, as an example to conduct a risk assessment of urban waterlogging with high-resolution remote sensing images and high-precision digital elevation models to further analyze the spatial distribution characteristics of waterlogging risk. Results indicate that waterlogging risk in the city proper of Ningbo is mainly low risk, accounting for $36.9 \%$. The higher-risk and medium-risk areas have the same proportions, accounting for $18.7 \%$. They are followed by the lower-risk and high-risk areas, accounting for $15.5 \%$ and $9.6 \%$, respectively. In terms of space, waterlogging risk in the city proper of Ningbo is high in the south and low in the north. The high-risk area is mainly located to the west of Jiangdong district and the middle of Haishu district. The low-risk area is mainly distributed in the north of Jiangbei district. These results are consistent with the historical situation of waterlogging in Ningbo, which prove the effectiveness of the risk assessment model and provide an important reference for the government to prevent and mitigate waterlogging. The optimized risk assessment model is also of importance for waterlogging risk assessments in coastal cities. Based on this model, the waterlogging risk of coastal cities can be quickly assessed, combining with local characteristics, which will help improve the city's capability of responding to waterlogging disasters and reduce socio-economic loss.
\end{abstract}

Keywords: urban waterlogging; risk assessment; GIS; Ningbo

\section{Introduction}

With the continuous intensification of global warming and the rapid development of urbanization, extreme rainfall events occur frequently, which consequently lead to increased urban waterlogging [1]. The rise in atmospheric temperature under the greenhouse effect not only leads to more evaporation, but also increases the atmosphere's ability to retain moisture [2]. Rainstorm and waterlogging disasters caused by heavy rain or typhoons have become one of the most common and serious natural disasters in many large cities in the world, especially in coastal regions. According to the survey, China is currently one of the most countries prone to floods in the world, among which the eastern coastal provinces and cities, Sichuan, Chongqing, and the middle reaches of the Yangtze River are the areas at risk [3]. The impacts of typhoons and storm surges on coastal areas are sudden and destructive, which can result in seawater intrusion, coastal erosion, the destruction of urban infrastructure, and even a large number of deaths and economic loss [4]. Waterlogging is one of the main problems faced by most cities in China, which directly restricts the urbanization process [5]. In 2018, 31 provinces in China suffered from flooding, affecting 55,765,500 people. More specifically, 83 cities experienced flooding, which caused 
a direct economic loss of CNY 161.547 billion [6]. Increasing urbanization also means that more people are affected by waterlogging disasters; for example, waterlogging disasters can cause significant health losses, including deaths, accidents, mental health problems, infectious diseases, etc. [7]. Waterlogging prevention and control solutions play an important role in alleviating the conflict between man and nature and promoting healthy and sustainable developments of cities. Consequently, scientific and accurate risk assessments are an important basis for reducing costs and effectively preventing urban waterlogging. It is also of importance for improving the level of urban management and optimizing urban planning and design.

Risk assessment models of urban waterlogging are mainly based on remote sensing images combining with geospatial data to build the model. However, the accuracy of remote sensing images and spatial data is not high. High-resolution remote sensing images can help to better identify land types and subtle topographical fluctuations which can affect the flow of water bodies. Thus, this study used high-resolution remote sensing images and high-precision digital elevation models to show changes in land use type and terrain. Given that waterlogging is caused by poor drainage and water accumulation, this study introduced the pumping station flow to the selection of indicators. At the same time, this study added indicators, such as road density, to construct the optimized risk assessment model from the perspective of the large measuring scale, which could assess waterlogging risk comprehensively. Based on the principle of natural disaster risk analysis, this study evaluated waterlogging disaster risk from the perspectives of dangerousness, sensitivity, and vulnerability.

As a typical coastal city in the Yangtze River Delta, Ningbo has experienced frequent waterlogging disasters, which adversely affect urban development and people's lives. To explore the distribution of waterlogging disaster risk in Ningbo and provide scientific references for future waterlogging prevention and control, this study takes the city proper of Ningbo as an example to comprehensively assess waterlogging risks, including dangerousness, sensitivity, vulnerability, by optimizing the urban waterlogging risk assessment model. The results are visualized with the help of ArcGIS 10.2. This study aims to explore theories and methods of large measuring scale and refined urban waterlogging risk assessments through an optimized risk assessment model and further provide support for disaster risk management, prevention, and mitigation planning in coastal cities.

\section{Literature Review}

\subsection{Urban Waterlogging}

Urban waterlogging refers to the phenomenon where heavy precipitation or continuous precipitation exceeds the drainage capacity of cities and towns, resulting in stagnant water disasters on the urban surface [8]. The increasingly frequent occurrence of urban waterlogging events has attracted the wide attention of scholars. Existing research on urban waterlogging mainly focuses on the following aspects: reasons for urban waterlogging; the application of urban rain flood models; and waterlogged risk assessment.

A large number of studies have shown that natural factors (precipitation and topography) $[9,10]$, as well as social factors, have increasingly significant impacts on urban waterlogging [11,12]. Urban construction changes its micro-topography which may hinder urban waterlogging management. This means that the emergence of underground space, bridges and tunnels increase the possibility of stagnant water and the difficulty of drainage. Additionally, with the rapid development of urbanization, a large number of original cultivated land, woodland, green belts, rivers and lakes have been replaced by building land, and the city has been "cemented" with a "hard bottom". Rainwater is unable to infiltrate in the face of heavy rainfall, which shortens the confluence time of rainfall and forms a peak flow in a short time. When the amount of rain exceeds the drainage capacity of the drainage system, waterlogging disasters are instigated. In addition, the shape of the river network is artificially changed in the process of urbanization, and the construction of 
low-standard and old urban drainage facilities makes the drainage system unable to meet the rapid growth of drainage demands brought by extreme precipitation.

From the perspective of the application of urban rain flood models, it can be divided into three stages in developed countries. The first stage from 1889 to 1971 mainly explored the calculation methods and related theories of urban runoff, which laid a theoretical foundation for the next stage of model research [13-15]. The second stage from 1972 to 1990 witnessed the rapid development of urban rain flood models, and many models were proposed in this stage including the water storage overflow treatment model (Storm), the drainage area simulation model (ILLUDAS), the snow melting runoff model (SRM), and the rainwater management model (SWMM) [16]. The third stage from 1991 onwards considers the stable development of urban rain flood models, and these models are widely applied to the related research of urban [17-19].

Disaster risk assessment, as the core content of disaster risk management, is a hot topic in international disaster research [20-22]. In terms of the evaluation scale, communities, residences, and underground transportation facilities of a certain city are usually selected to assess local waterlogging risks in existing studies [23-25]. Overall urban waterlogging risk can also be assessed by aggregating the evaluation results obtained from those micro scales [26,27]. In terms of case areas, existing studies often focus on coastal cities because urban waterlogging is mainly affected by heavy and continuous rainfall [28]. However, in recent years, many inland cities have experienced frequent waterlogging disasters, which has attracted much attention from researchers [29,30]. In terms of the evaluation method, the risk assessments have changed from qualitative research to quantitative research, including geomorphological methods, hydrological and hydrodynamic modeling, system simulation modeling, scenario simulation analysis, coupling methods based on remote sensing and geographic information systems, statistical analysis based on text, and the index system method [31-38]. Most studies have focused on establishing the risk assessment models by constructing the waterlogging disaster index systems because of its rich content and concise and fast features.

\subsection{Risk Assessment of Urban Waterlogging}

\subsubsection{Formation Mechanism of Natural Disaster Risk}

The word "risk" has an ancient maritime origin, from the words "wind" and "insurance": the wind often brings uncertain insurances when fishermen sail out to sea [39]. Risk refers to the objective danger, which contains two meanings: one is the possibility of injury and loss of the objective entity; and the other is some kind of harm that may occur in the future [40]. The United Nations Department of Humanitarian Affairs defines disaster risk as the loss of people's lives, property, and expected activities caused by specific disasters in a certain area and within a given period of time [41]. In the research on the formation mechanism of natural disaster risk, different researchers put forward many different expression patterns according to their own understanding. For example, Maskrey believed that natural disaster risk is the algebraic sum of hazard and vulnerability [42]. In 1991, the disaster risk expression model proposed by the United Nations was expressed as "natural disaster risk $=$ dangerousness $\times$ vulnerability" [43]. Okada suggested that the risk of natural disasters is formed by the interaction of dangerousness, exposure, and vulnerability [44]. Shi (2002) argued that natural disasters occur due to the action of disaster-causing factors on the disaster-bearing body caused by the prone environment. In conclusion, most scholars identify risk mainly from three aspects, including dangerousness, sensitivity, and vulnerability [45]. In addition, Zhang and Li (2007) added the factor of "disaster prevention and mitigation" to express the response ability of cities to disasters. Natural disaster risk is further expressed as "natural disaster risk $=$ dangerousness $\times$ exposure $\times$ vulnerability $\times$ disaster prevention and mitigation capability". This expression has also been recognized by many scholars and has been applied to the assessment of all kinds of natural disasters [46]. 


\subsubsection{Waterlogging Risk Assessment Model}

From the perspective of disaster science, the natural disaster risk system is composed of disaster-causing factors, prone environment, and the disaster-bearing body, which interact with each other and reflect the relationship between human society and the natural environment. There is no causal relationship between the three, but they interact and relate to each other to form a complex system with multiple feedback relationships. The risk assessment of urban waterlogging disaster is a multi-factor comprehensive analysis work on the basis of urban waterlogging risk, waterlogging sensitivity, waterlogging vulnerability, and related uncertainty. Therefore, in the construction of an urban waterlogging risk assessment model, the evaluation indicators are mainly selected from the aspects of risk, vulnerability, vulnerability, etc. Internet open data and big data analysis have played an important role in improving residents' quality of life and rational allocation of resources. Therefore, some scholars believe that open urban data information has great potential for risk assessment because of its openness, timeliness, and richness. Based on the urban big data, a risk assessment model is constructed by selecting indicators such as precipitation, population, and urban public infrastructure from three aspects: disaster inducing factors, vulnerability, and exposure [47]. Some scholars combine the data obtained by web crawler technology with traditional statistical text data, and select six indicators: precipitation and duration, altitude and slope, and land use and population density to evaluate the flood disaster in urban areas [31]. Some scholars use the risk assessment expression model proposed by Maskrey to build a risk assessment model from two aspects of harm and vulnerability. In the aspect of waterlogging hazard assessment, in addition to the consideration of precipitation, the risk potential triggering factors are also introduced, including flow accumulation area, elevation (DEM), slope, water system buffer zone and land cover type. GDP, population, and grain production indicators are selected to build risk assessment models to evaluate the waterlogging risk of inland cities in China [30]. When some scholars evaluate the risk of waterlogging in large regions and many cities, they comprehensively analyze the disaster intensity, socio-economic impact, and the adaptability of waterlogged cities, and select precipitation as the disaster intensity index, taking into account the same disaster. Big cities will suffer greater losses in disasters; the total urban population and GDP are the two selected indicators to consider the socio-economic exposure. In dealing with waterlogging disasters, drainage pipe density, river network density and urban greening rate play an important role in alleviating waterlogging intensity; thus, these three indicators are selected to show urban adaptability. Finally, the waterlogging risk grade of China's eastern coastal cities is obtained [48]. To conclude, in the construction of a waterlogging risk assessment model, precipitation, as the main disaster factor of urban waterlogging, is the main index to determine the risk grade; in the selection of a prone environment, all kinds of topography, river network, land use type, drainage system and so on have different effects on waterlogging. Therefore, these indicators are selected to reflect the triggering effect of the overall urban environment on waterlogging. In terms of disaster-bearing bodies, this paper mainly considers the urban population, public infrastructure, economic development, and other factors that are easily affected by waterlogging disasters.

\section{Methodology}

\subsection{Research Area}

The city proper of Ningbo refers to the districts of Haishu, Jiangdong, and Jiangbeibefore the planning adjustment in 2016. They are located in the middle of Ningbo with approximately $275.5 \mathrm{~km}^{2}$ within the junction area of the Yuyao River, Yongjiang River and Fenghua River. According to statistics, the registered population in the city proper of Ningbo was 829,427 by the end of 2016 . More than 80 primary and secondary rivers are in the area, with approximately $2 \mathrm{~km}^{2}$ of inland water. Specifically, the Yongiiang River is located to the north of Jiangdong district and the southeast of Jiangbei district. To the east of Jiangdong and Jiangbei districts is the Fenghua River and the Yuyao River, respectively. Jiangbei district has dense water networks and abundant water resources. 
Six main reservoirs were built in the upper mountainous area, including three crucial reservoirs, namely, Hero Reservoir, Maoli Reservoir, and Langjiaping Reservoir. Haishu district faces Fenghua River in the east and Yuyao River in the north. Figure 1 illustrates the research area of this study.

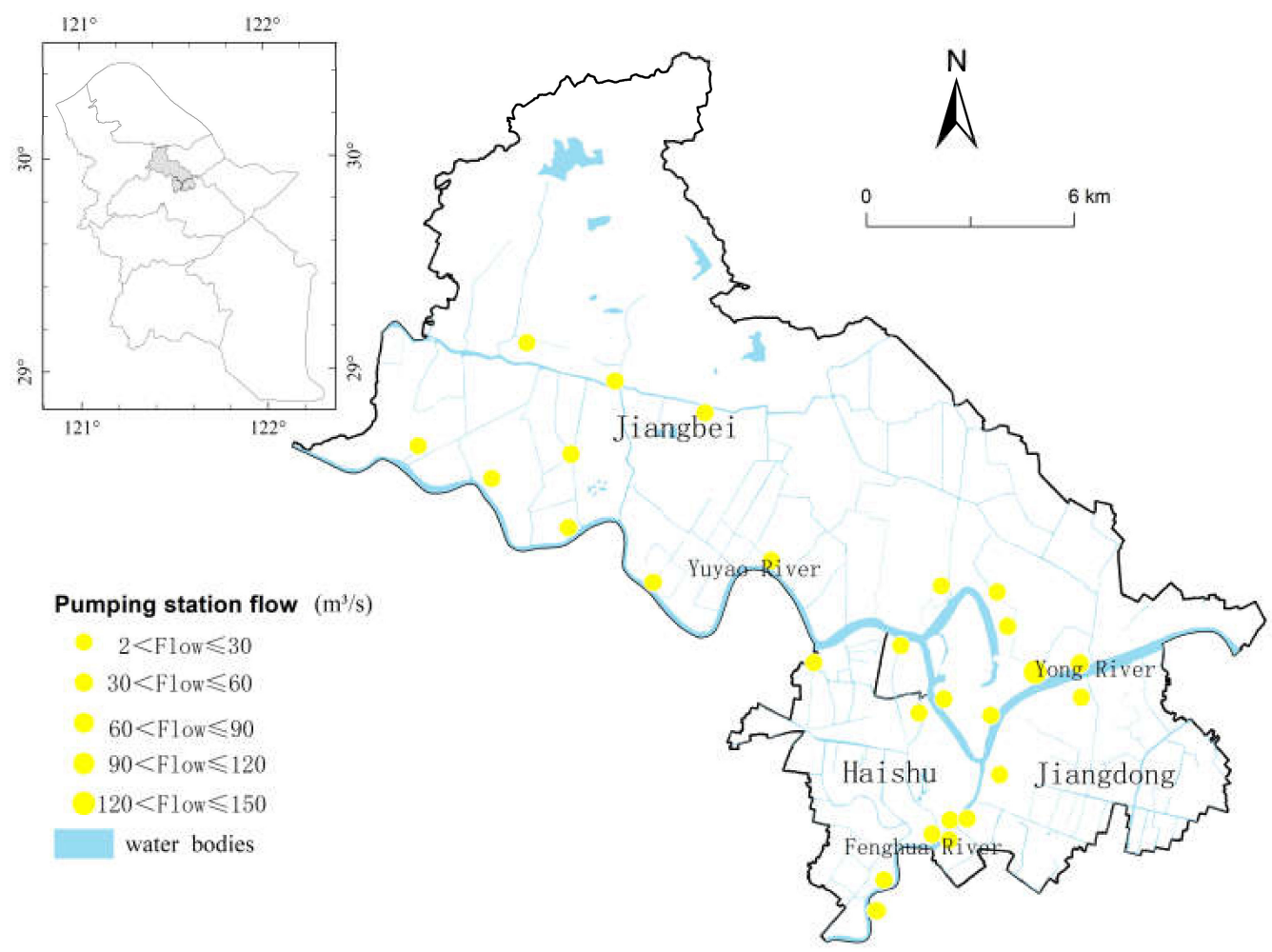

Figure 1. The map of the study area.

\subsection{Data Collection}

Based on the analysis of the factors affecting waterlogging in Ningbo, this study divides the collected data into geospatial data and socioeconomic category. Table 1 shows the specific data content.

Table 1. Research data.

\begin{tabular}{|c|c|c|}
\hline Data Category & Data & Sources \\
\hline \multirow{8}{*}{ Geospatial data } & $\begin{array}{l}\text { DEM (Digital Elevation Model) data in the city proper } \\
\qquad(2 \times 2 \mathrm{~m})\end{array}$ & Surveying and Mapping Institute of Ningbo \\
\hline & Soil classification map of Ningbo (1:1 million) & Institute of Soil Science, Chinese Academy of Sciences \\
\hline & $\begin{array}{l}\text { Remote sensing images in the city proper in } 2016 \\
\qquad(0.5 \times 0.5 \mathrm{~m})\end{array}$ & Bureau of Land and Resources of Ningbo \\
\hline & The type of land use in $2016(1: 10,000)$ & Bureau of Land and Resources of Ningbo \\
\hline & Drainage pump station of main rivers in the city proper & Field investigation \\
\hline & Boundary of the administrative district in the city proper & The research group \\
\hline & Water accumulation points in the city proper in 2016 & News reports and field investigation \\
\hline & Road distribution of Ningbo (county level) & Electronic Map of Ningbo (2015) \\
\hline \multirow{2}{*}{ Socioeconomic data } & $\begin{array}{l}\text { Population information of each street in the city proper } \\
\text { in } 2016\end{array}$ & 2017 Ningbo Statistical Yearbook \\
\hline & Soil property classification & Zhejiang Soil History \\
\hline
\end{tabular}




\subsection{Data Processing}

On the basis of the basic evaluation unit of a $15 \mathrm{~m} \times 15 \mathrm{~m}$ grid, this study uses GIS spatial analysis to spatialize the influencing factors of waterlogging. Figure 2 shows the flow chart of data processing.

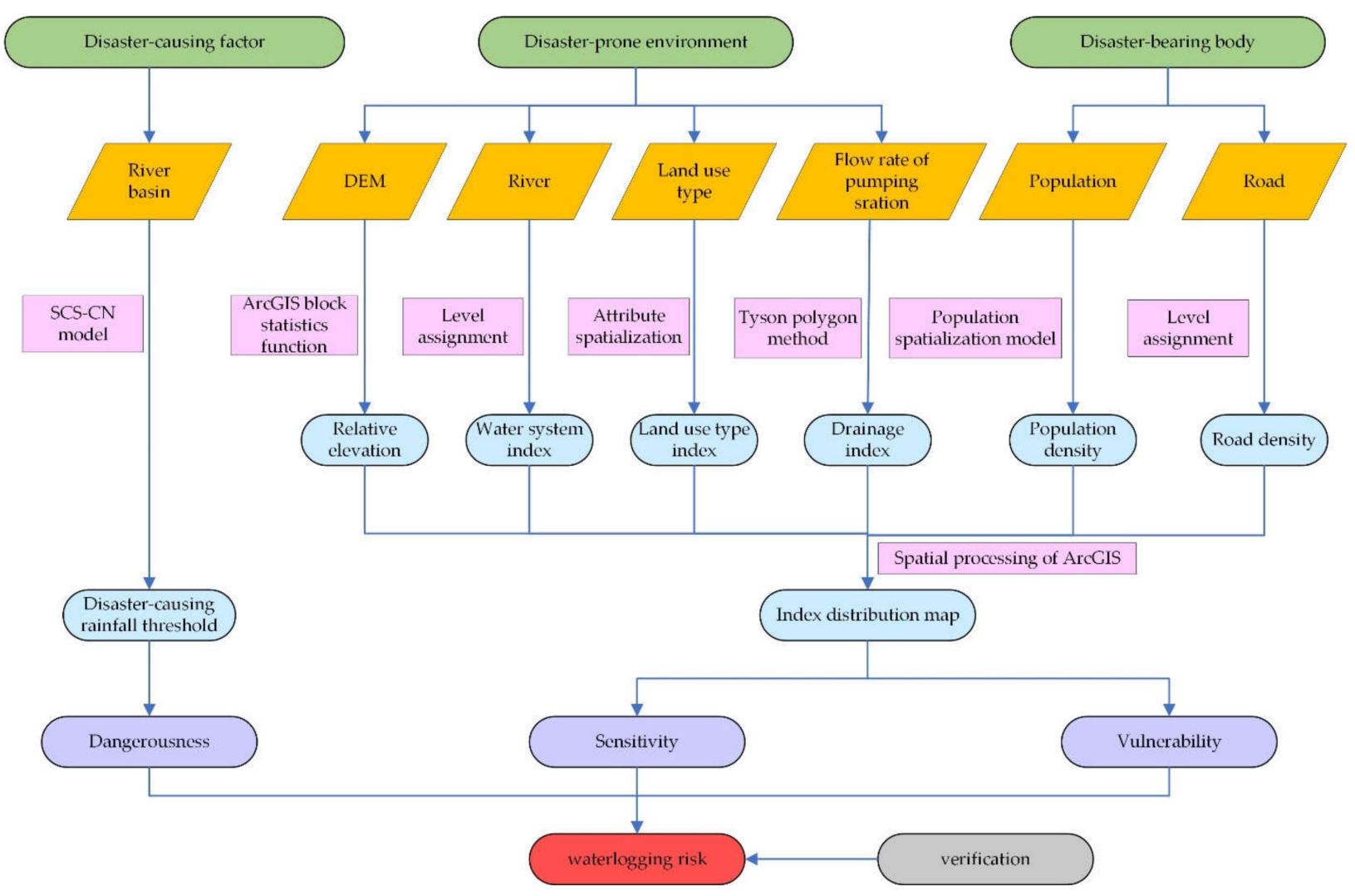

Figure 2. The flow chart of data processing.

The rivers in the city proper are divided into 17 basins, and the rainfall thresholds of each basin are inverted on the basis of the SCS-CN (Soil Conservation Service curve number) model (see Table 2). Using DEM (Digital Elevation Model) data with a resolution of $2 \mathrm{~m} \times 2 \mathrm{~m}$ in the city proper of Ningbo, the relative elevation standard deviation was calculated through the block statistics function of the grid neighborhood analysis in the GIS spatial analysis (see Figure 3). Given that different levels of rivers have different impacts on waterlogging disasters, this study assigned the rivers with different values according to the distance of the river buffer zone. More specifically, the buffer zones of Yuyao River, Yongjiang River and Fenghua River were assigned values of 0.9, 0.8, 0.7, and 0.6, from short to long distance, and the buffer zones of major inland rivers were assigned values of $0.8,0.7,0.6$, and 0.5 (see Figure 4). The types of land use in the city proper of Ningbo were spatialized according to attributes (see Figure 5). By spatializing the flow data of the pumping station in the old city of Ningbo with GIS, this study used the Tyson polygon method to simulate the drainage area of each pumping station to show the distribution of drainage capacity (see Figure 6). The population data in the city proper of Ningbo was sorted on the basis of the population spatialization model (see Figure 7). Different levels of roads have different capacities, and the impacts on waterlogging disasters are also different. Therefore, the road capacity was weighted on the basis of previous research and road grades. For example, this study assigned values of $0.24,0.24,0.20,0.17$, and 0.15 to railways, high-speed national roads, provincial roads, county roads, and township and village roads, respectively (see Figure 8 ). Finally, the index distribution map of the waterlogging risk assessment in the city proper of Ningbo was formed. 
Table 2. Simulated rainfall threshold of different water depth in the city proper of Ningbo (unit: $\mathrm{mm}$ ).

\begin{tabular}{|c|c|c|c|c|c|c|c|c|c|}
\hline Basin $\mathrm{Nu}$ & & & & & & & & & \\
\hline & 1 & 2 & 3 & 4 & 5 & 6 & 7 & 8 & 9 \\
\hline \multicolumn{10}{|l|}{ Depth of Stagnant Water } \\
\hline $0.1 \mathrm{~m}$ & 16.2 & 5.6 & 9.95 & 5.37 & 16.01 & 10.62 & 10.51 & 10.85 & 6.65 \\
\hline $0.2 \mathrm{~m}$ & 25.5 & 14.65 & 14.95 & 10.1 & 21.08 & 17.6 & 13.53 & 16.1 & 8.46 \\
\hline $0.6 \mathrm{~m}$ & 114.1 & 50.14 & 40.86 & 30 & 54.9 & 54.78 & 30.38 & 53.67 & 58.35 \\
\hline $1 \mathrm{~m}$ & 189 & 148.22 & 74.11 & 45.51 & 91.96 & 73.07 & 92.9 & 96.19 & 198.12 \\
\hline \multicolumn{10}{|c|}{ Basin Number } \\
\hline & 10 & 11 & 12 & 13 & 14 & 15 & 16 & 17 & 10 \\
\hline \multicolumn{10}{|l|}{ Depth of Stagnant Water } \\
\hline $0.1 \mathrm{~m}$ & 10.63 & 9.28 & 11.62 & 37.16 & 10.83 & 8.76 & 25.24 & 8.27 & 10.63 \\
\hline $0.2 \mathrm{~m}$ & 14.7 & 12.74 & 14.14 & 66.45 & 14.71 & 14.7 & 37 & 10.71 & 14.7 \\
\hline $0.6 \mathrm{~m}$ & 42.59 & 39.01 & 38.17 & 160 & 33 & 51 & 95.06 & 23.68 & 42.59 \\
\hline $1 \mathrm{~m}$ & 95.19 & 58 & 138.78 & 198 & 40.59 & 104.95 & 159.2 & 38.39 & 95.19 \\
\hline
\end{tabular}

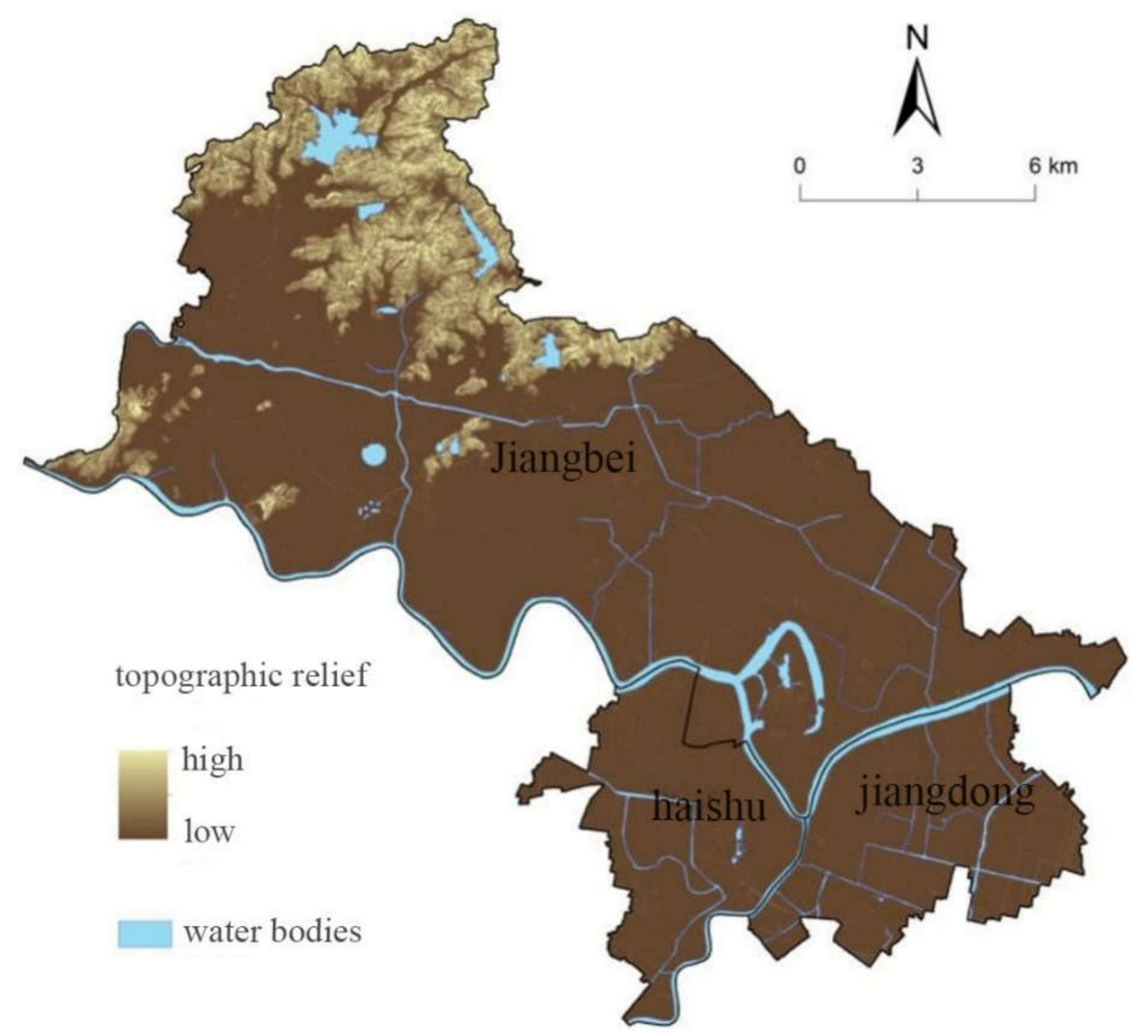

Figure 3. The spatial distribution map of topographic relief degree in the city proper of Ningbo. 


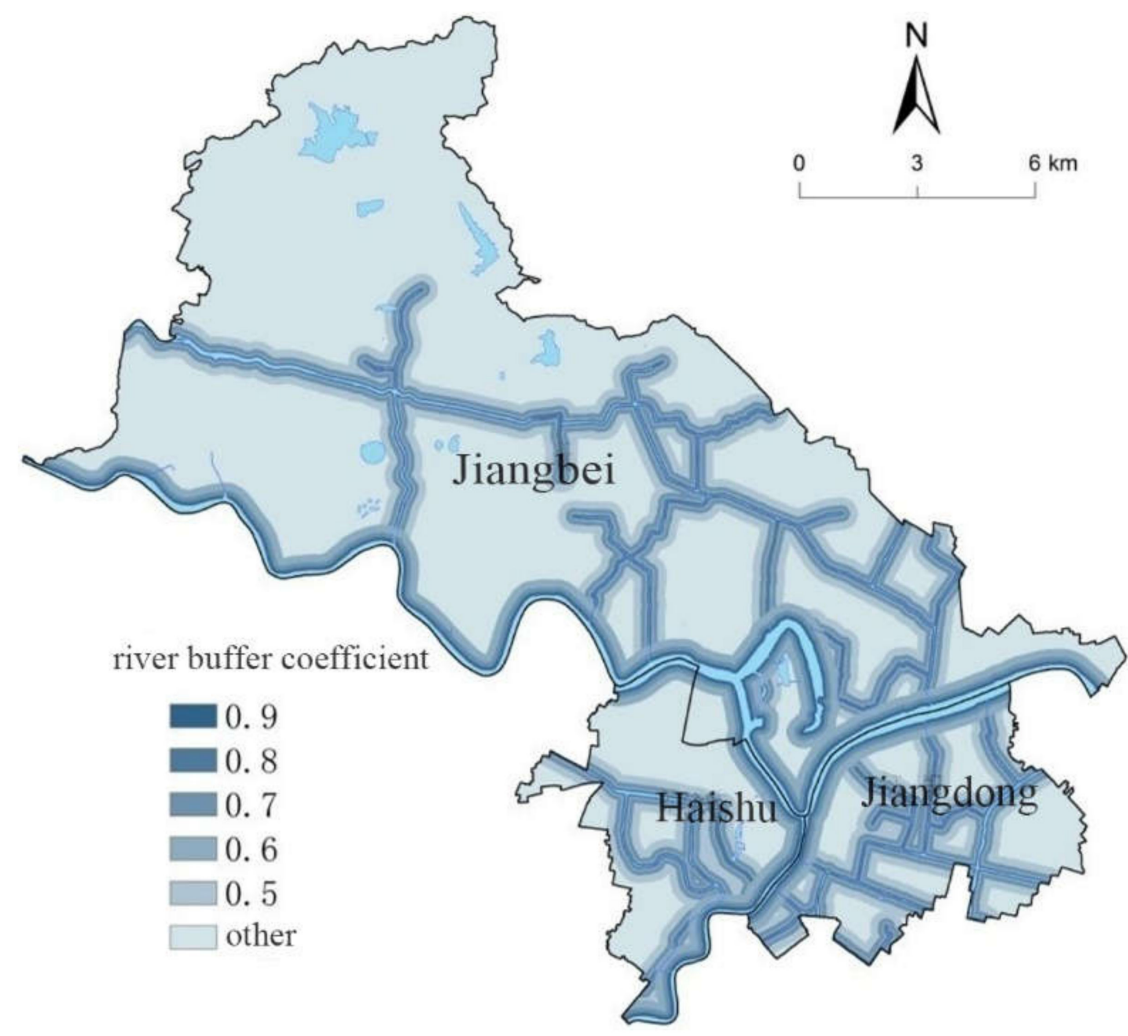

Figure 4. Buffer zone map of main rivers in the city proper of Ningbo.

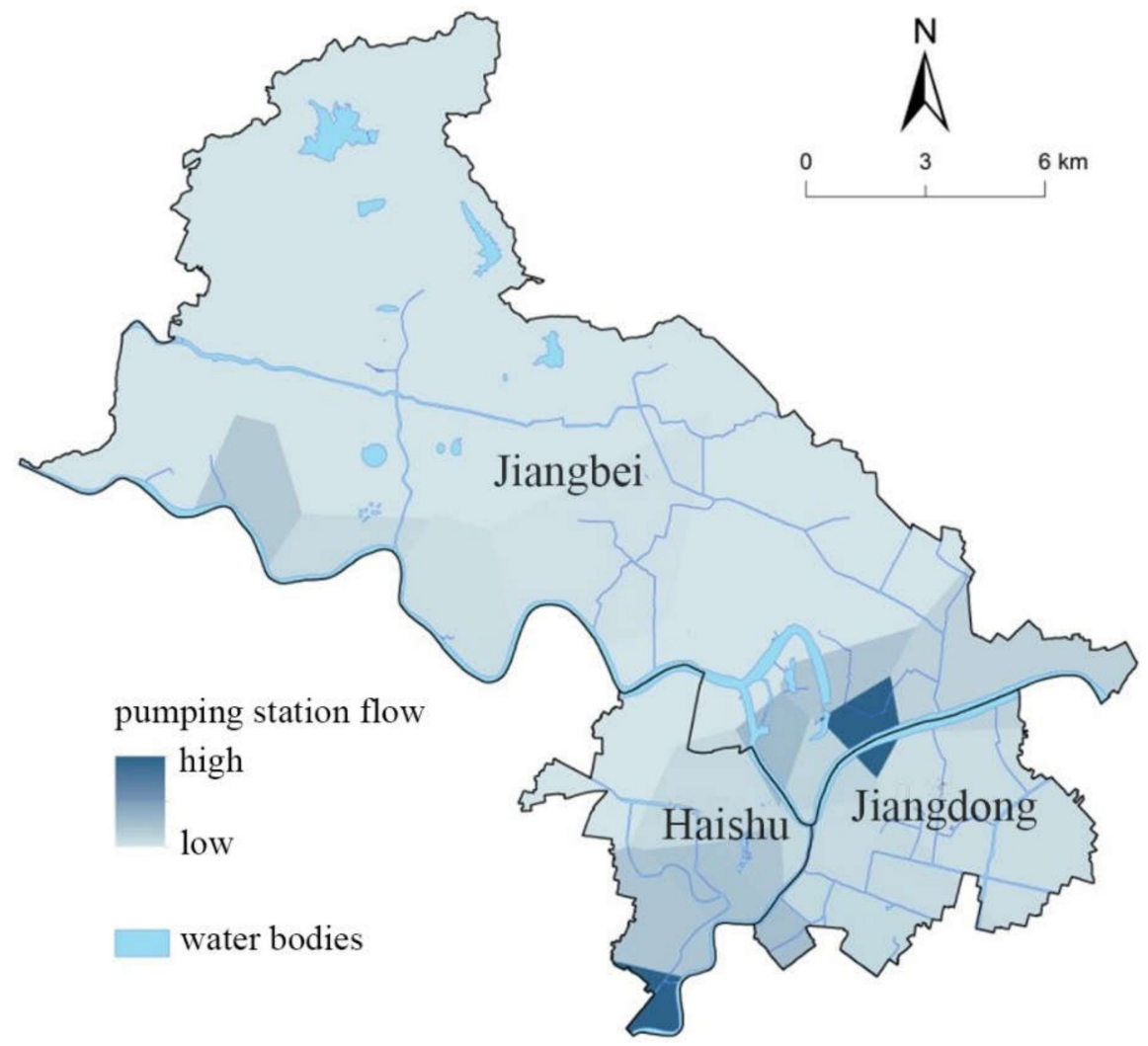

Figure 5. Flow chart of pumping stations in the city proper of Ningbo. 


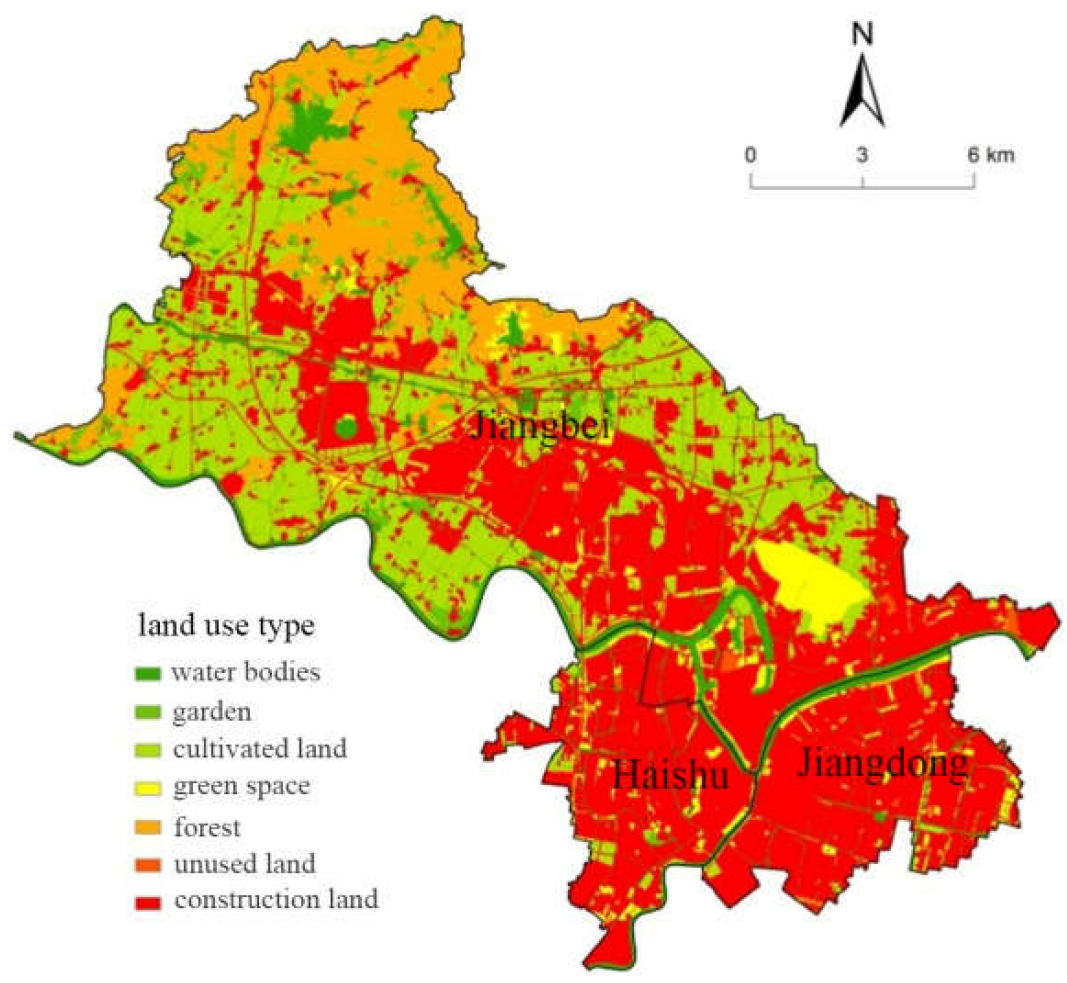

Figure 6. Land use classification map in the city proper of Ningbo.

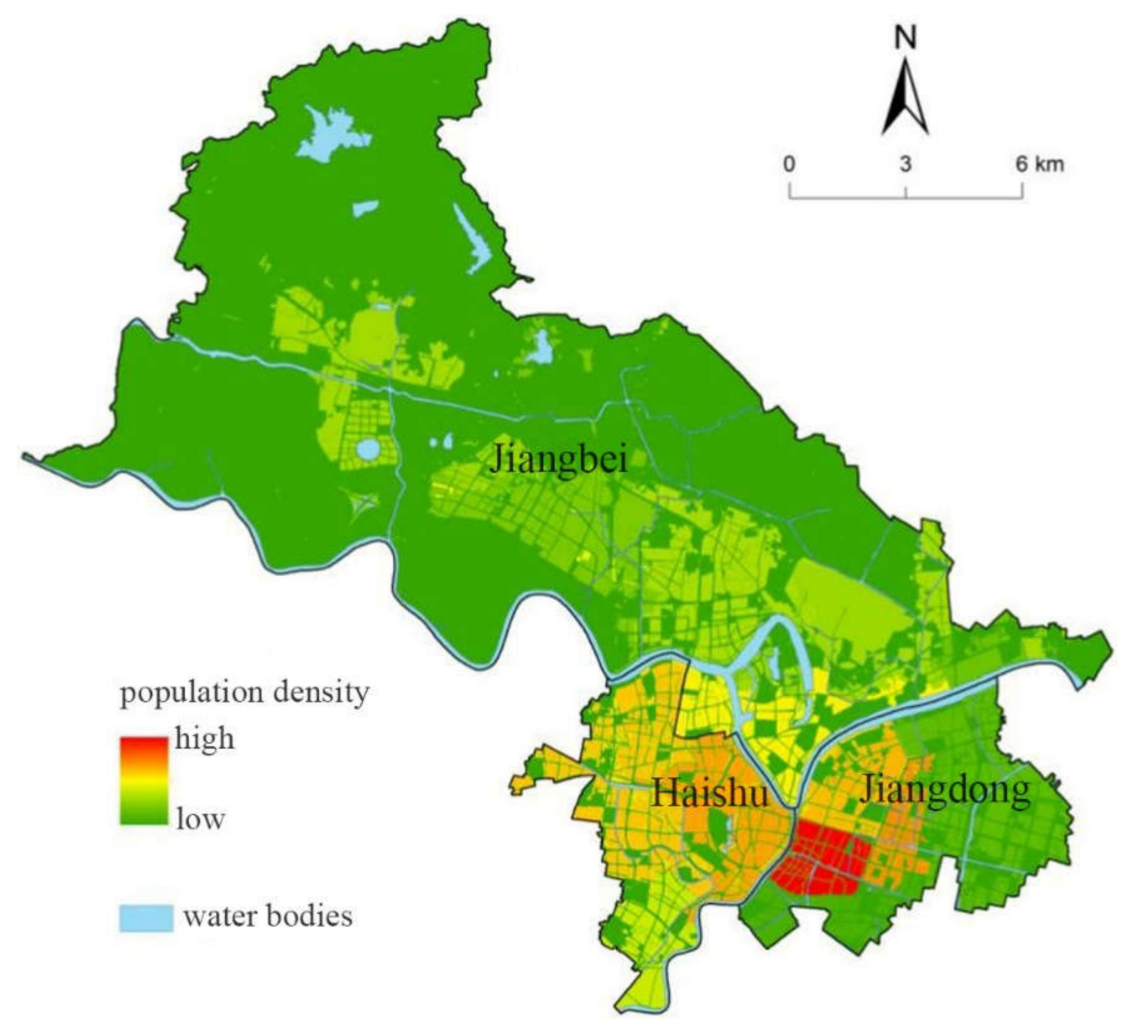

Figure 7. Population density distribution map in the city proper of Ningbo. 


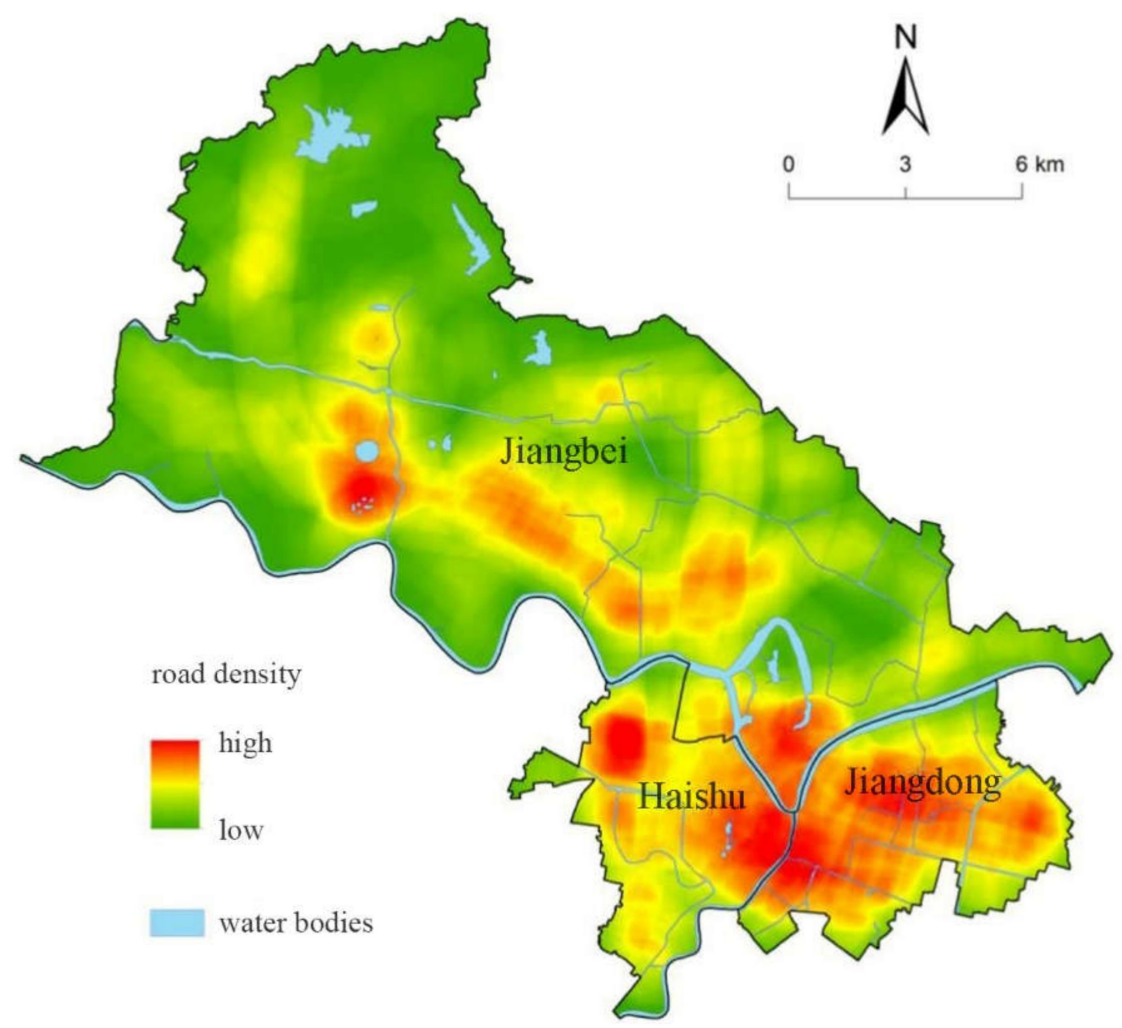

Figure 8. Road density spatial distribution map in the city proper of Ningbo.

\subsection{Risk Indicator Weight}

The indicator weight reflects the relative importance of each indicator in the risk assessment. The analytic hierarchy process (AHP) method was proposed by Professor T. L. Saaty of the University of Pittsburgh [49] in the mid-1970s. It is an analysis method wherein the research object is treated as a system and then analyzed in a way of decomposition, comparison, judgment, and synthesis. A complex problem can be decomposed into various constituent factors, which are grouped according to the dominant relationship to form an orderly hierarchical structure. According to AHP, the weight value of each indicator can be determined.

\subsection{Risk Assessment Model}

By comprehensively referring to existing studies [50-52] and combining with the characteristics of waterlogging in the city proper of Ningbo, the conceptual model of waterlogging risk assessment is expressed as follows:

$$
D R I=Q_{1} \times H+Q_{2} \times E+Q_{3} \times V,
$$

where $D R I$ is the dependent variable representing the indicator of urban waterlogging disaster risk; $H, E$, and $V$ are independent variables representing waterlogging dangerousness, waterlogging sensitivity, and waterlogging vulnerability, respectively; and $Q_{1}, Q_{2}$, and $Q_{3}$ represent the corresponding weight of each indicator.

\section{Results}

\subsection{Urban Waterlogging Risk Assessment Model}

From the perspective of disaster science, the natural disaster risk system is composed of disaster-causing factors, a disaster-prone environment, and a disaster-bearing carrier. These three parts that interact with one another reflect the mutual relationship between human society and the natural environment. This study constructs the index system by optimizing the existing research models (see Table 3 ) and comprehensively evaluating wa- 
terlogging risk from the three perspectives of dangerousness, sensitivity, and vulnerability. The drainage capacity of the city proper was explained by increasing the flow of pumping stations in the sensitivity assessment, and the road system indicator was added in the vulnerability assessment. They all improved the waterlogging risk assessment model in the city proper of Ningbo.

Table 3. Index system of waterlogging risk assessment in Ningbo.

\begin{tabular}{cccc}
\hline Target Layer & Criterion Layer & Indicator Layer & Scheme Layer \\
\hline & Dangerousness & Precipitation & Catastrophic rainfall threshold \\
& & Terrain & Terrain relief \\
Waterlogging risk assessment & Sensitivity & Water system & River buffer \\
& & Drainage capacity & Pump station flow \\
& Surface features & Land use type \\
& Pulnerability & Population & Population density \\
& & Road density & Road den \\
\hline
\end{tabular}

\subsection{Risk Assessment Based on the Risk Assessment Model}

\subsubsection{Calculation of Risk Indicator Weight}

The relative importance of the indicators in this study was jointly determined through historical waterlogging case analysis, expert advice, and research group discussions. A judgment matrix could not be formed because dangerousness had only one indicator. Thus, its weight was equal to the weight of waterlogging dangerousness. For the weight of waterlogging dangerousness, the existing risk assessment model had a weight value ranging from 0.409 to 0.423 . The occurrence of waterlogging in the city proper of Ningbo is mainly affected by meteorological factors, such as continuous precipitation, heavy rain, and typhoons. Thus, the weight of waterlogging dangerousness was highlighted with the value of 0.5 , which will help to accurately assess the waterlogging risk in the city proper. Table 4 shows the waterlogging risk indicator weight in the city proper of Ningbo.

Table 4. The waterlogging risk indicator weight in the city proper of Ningbo.

\begin{tabular}{cccc}
\hline Indicator Type & Weight & Indicator Layer & Weight \\
\hline Dangerousness & 0.5 & Catastrophic rainfall threshold & 0.5 \\
& & Land use type & 0.0325 \\
Sensitivity & 0.25 & Terrain relief & 0.0975 \\
& & Pump station flow & 0.0475 \\
Vulnerability & \multirow{2}{*}{0.25} & River buffer & 0.0725 \\
& & Population density & 0.1675 \\
& & Road density & 0.0825 \\
\hline
\end{tabular}

\subsubsection{Waterlogging Risk Assessment in the City Proper of Ningbo}

\section{Waterlogging Dangerousness Assessment}

Under the same depth of water accumulation, the area with less disaster-causing rainfall is more prone to experience waterlogging and faces greater risks. In this area, different depths of water accumulation have different impacts on the degree of waterlogging disasters. The deeper the water accumulation depth, the greater the impact of waterlogging disasters on the area. Thus, the disaster-causing rainfall at different levels was used as the indicator for the dangerousness assessment of waterlogging disaster-causing factors in the city proper of Ningbo.

According to related studies and the actual situation in Ningbo [53], different depths of stagnant water have different effects on people's health, life, property, and other aspects. That is, the deeper the depth of stagnant water, the more serious the damage. According to the waterlogging depth in Table 2, the level of waterlogging is divided. This study chooses 0.1 to $0.2 \mathrm{~m}$ as light waterlogging, 0.2 to $0.6 \mathrm{~m}$ as moderate waterlogging, and 0.6 
to $1 \mathrm{~m}$ as heavy waterlogging. On the basis of Table 2, this study classified the levels by considering the minimum level of water accumulation at the same level and re-assigned the waterlogging disaster-causing rainfall for different grades (see Table 5).

Table 5. The assignments of disaster-causing rainfall threshold for different levels.

\begin{tabular}{cccc}
\hline $\begin{array}{c}\text { Rainfall } \\
\text { Classification }\end{array}$ & $\begin{array}{c}\text { Light } \\
\text { Waterlogging }\end{array}$ & $\begin{array}{c}\text { Moderate } \\
\text { Waterlogging }\end{array}$ & Heavy Waterlogging \\
\hline$(5.73,10.1)$ & 5 & - & - \\
$(10.1,26.38)$ & 4 & 5 & 5 \\
$(26.38,38.89)$ & 3 & 4 & 4 \\
$(38.89,189)$ & 2 & 3 & 3 \\
$(189, \sim)$ & 1 & 2 & - \\
\hline
\end{tabular}

Note: "—" means a null value.

This study re-assigned the rainfall thresholds of the three waterlogging levels by using ArcGIS 10.2. Figure 8 indicates that the area with high waterlogging dangerousness in the city proper of Ningbo is mainly the middle of Jiangdong district and the southern part of Haishu district, because of the low and flat terrain and many impervious surfaces. Combined with low disaster-causing rainfall, heavy rainfall easily leads to stagnant water because the water does not flow easily, thereby bringing high risk. Most areas in the northern part of Jiangbei district are located in medium and low-dangerousness areas, and high-dangerousness areas are scattered. The disaster-causing rainfall in Jiangbei district with higher terrain is higher than that of areas with lower terrain; however, this condition is good for drainage under the same depth of water accumulation and means that the risk is lower. The waterlogging dangerousness in the city proper of Ningbo is mainly shown as low dangerousness, which accounts for $56.8 \%$, occupying half of the total area. Moreover, the areas with medium and high dangerousness account for $23.7 \%$ and $19.5 \%$, respectively.

2. Waterlogging Sensitivity Assessment

According to Table 4, waterlogging sensitivity assessments in the city proper of Ningbo assigned the indicators to the corresponding weighting coefficients. ArcGIS 10.2 was used to overlay the layers. The corresponding results are summarized in Figure 9. This study concluded that the land use type determined the distribution pattern of the medium and low sensitivity areas in the city proper of Ningbo, whereas the distribution of areas with high sensitivity was largely affected by the river networks. Most areas with medium and high sensitivity are located to the south of the city proper. The main reason is that these areas are mainly construction land with high density and covered with a single type of surface, which will promote the "urban rain island effect" and easily lead to extreme precipitation. The area with low sensitivity is located in the Changlong Mountain area with large undulations, to the north of Jiangbei district and the southwest of Jiangbei district, which is mainly used as cultivated land with good water permeability. The waterlogging sensitivity in the city proper of Ningbo is shown as moderately sensitive, accounting for $36.9 \%$. Moreover, the proportion of the area with high sensitivity, second-low sensitivity, and low sensitivity is $26.2 \%, 24.4 \%$, and $12.5 \%$, respectively. 


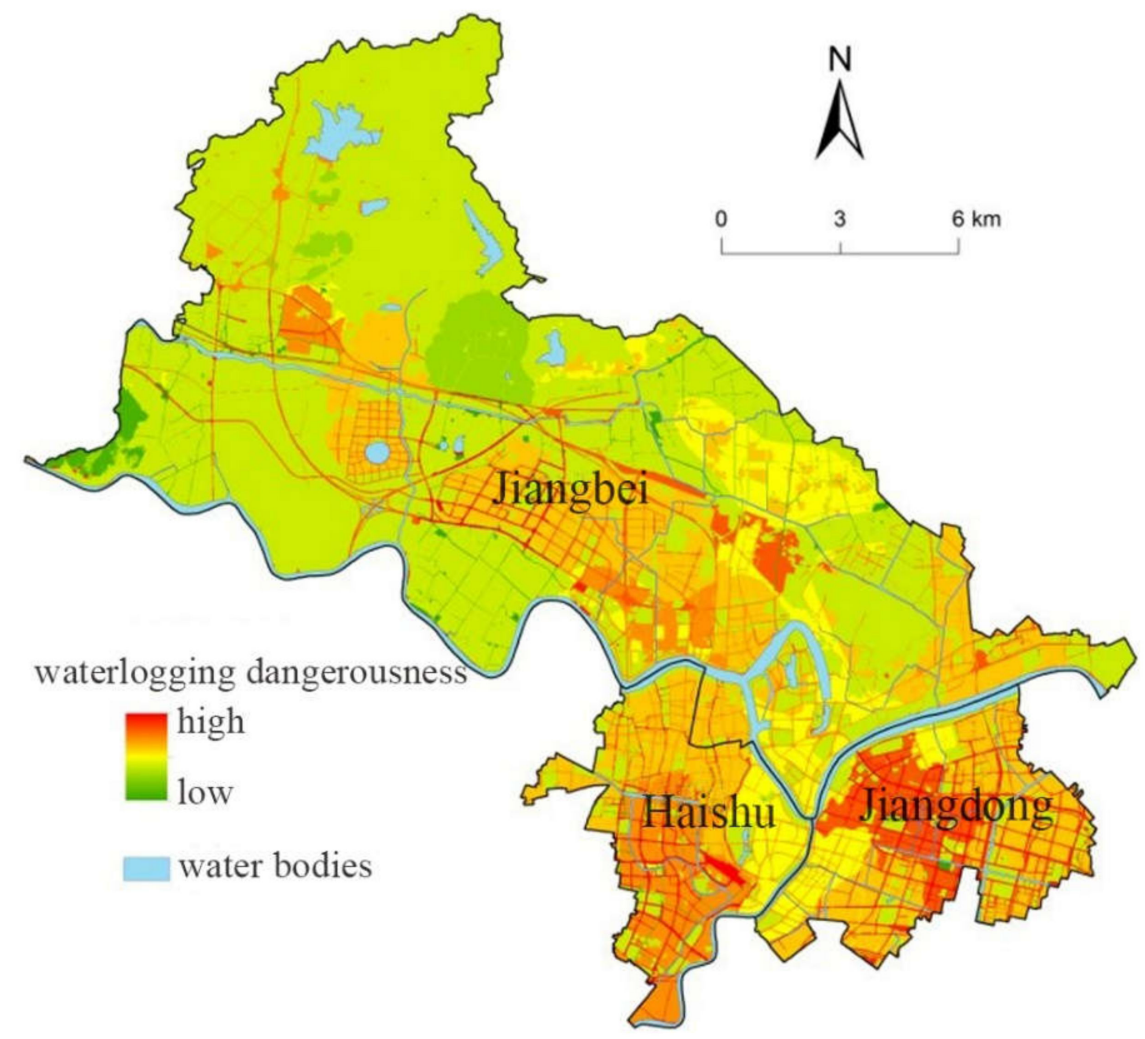

Figure 9. Waterlogging dangerousness distribution map in the city proper of Ningbo.

3. Waterlogging Vulnerability Assessment

According to Table 4 , the vulnerability assessment of waterlogging in the city proper of Ningbo assigned population density and road density to corresponding weighting coefficients. ArcGIS 10.2 was used to overlay the layers. Figure 10 concludes the results and shows that the areas with high vulnerability in the city proper of Ningbo are mainly distributed in the Sanjiangkou area, namely, the central and southern Jiangdong district, the eastern Haishu district, and the southern Jiangbei district. The main reason is that the Sanjiangkou area is the economic center of Ningbo, which has a concentrated population and high road density. A waterlogging disaster will cause huge social and economic loss. The northern part of Jiangbei district is a mountainous and forested area with sparse population. Therefore, most parts of this area show low vulnerability. The proportion of areas occupied by different grades of waterlogging vulnerability in the city proper of Ningbo gradually decreases from high vulnerability to low vulnerability and mainly shows low vulnerability, accounting for $37.6 \%$. Moreover, the areas with second-low vulnerability, medium vulnerability, and high vulnerability account for $30.5 \%, 23.2 \%$, and $8.5 \%$, respectively. 


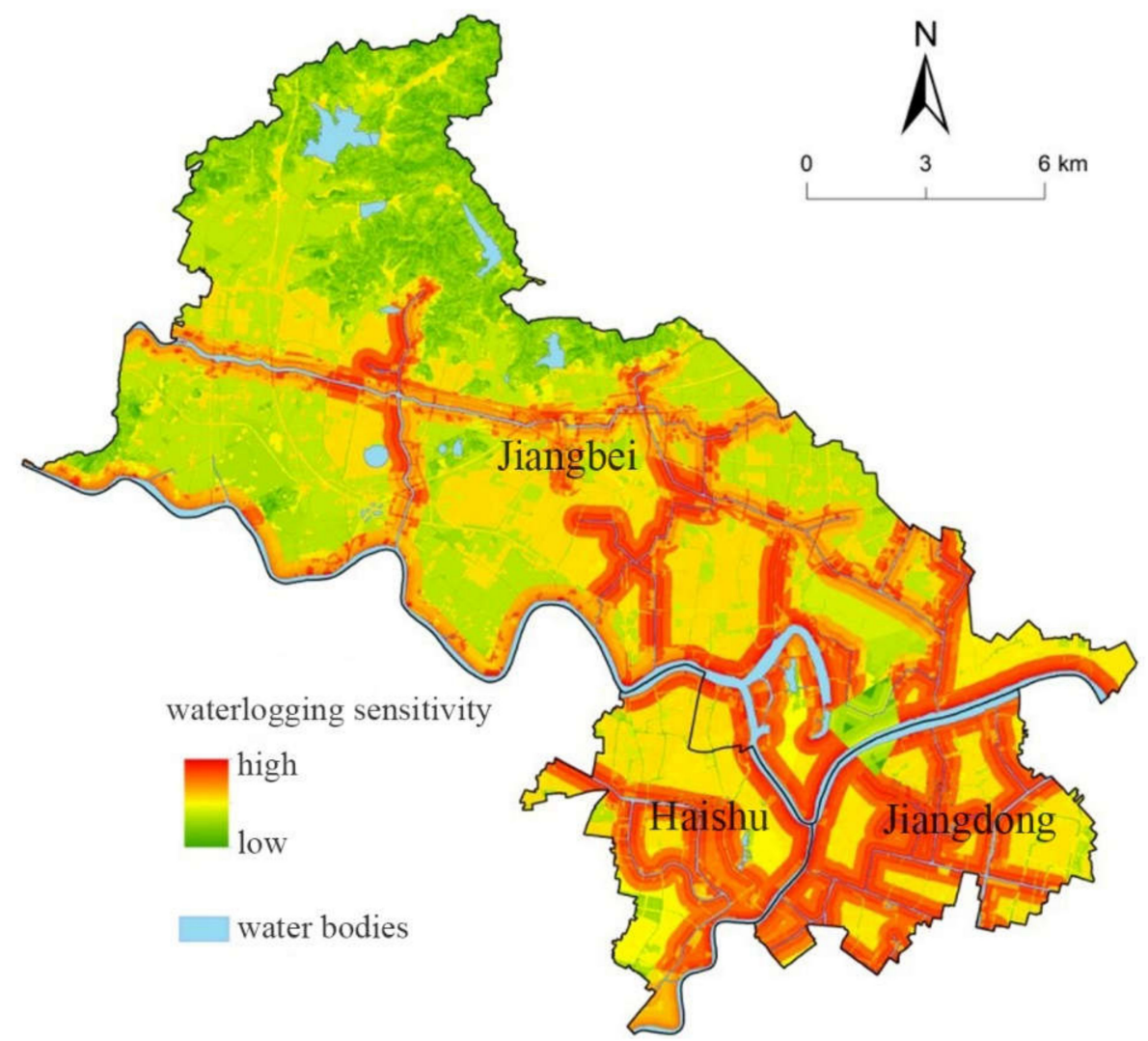

Figure 10. Waterlogging sensitivity distribution map in the city proper of Ningbo.

4. Comprehensive Waterlogging Risk Assessment in the City Proper of Ningbo

On the basis of the waterlogging risk evaluation system established in this study, weight coefficients, and the spatial distribution layer obtained from the above criterion layers, superimposed analysis was conducted in ArcGIS 10.2 to obtain the distribution map of waterlogging risk in the city proper of Ningbo. Moreover, this study divided the risk into five levels, namely, high-risk, higher-risk, medium-risk, lower-risk, and low-risk, by conducting the natural breakpoint classification method. Figure 11 indicates that the areas with high-risk in the city proper of Ningbo are mainly located to the west of Jiangdong district and the middle of Haishu district, and other areas are distributed in the south of Jiangbei district. For example, under the influence of Typhoon Fite in 2013, large areas of the city proper, including most of the low-level residential areas, were flooded; urban traffic was paralyzed; and the city proper lost powered. In particular, Xingning Road, Zhongxing Road, Jiefang South Road, Baizhang Road, Lianfeng Road, and other roads of high-risk areas were closed, and the lower floors of the houses in the Huangli community were flooded. Another example is Typhoon Dujuan in 2015. Water entered the low-level residential areas of Caoma Second Village, Shuguang Second Village, Liuting New Village, and Workers' New Village, and the roads were heavily flooded. The main reason is that the city proper of Ningbo is higher in the northwest and lower in the southeast. Stagnant water tends to gather in these low-lying areas once heavy rainfall occurs. To prevent the river from inverting, these areas can only be drained through the urban drainage system and gate pumps because of their proximity to the Yao River, the Fenghua River, and the Yongjiang River. However, the main urban drainage system is relatively underdeveloped, and the waterlogging risk is high. The higher-risk areas are mainly distributed in the Cicheng urban area in the northern part of Jiangbei and most areas of Haishu district. The medium and low-level risk areas are mainly located in the northern part of Jiangbei district, primarily because these high-lying areas have a sparse population distribution. Moreover, 
most parts of the Jiangbei district are paddy fields, woodlands, and gardens with good water permeability; thus, the risk will be low.

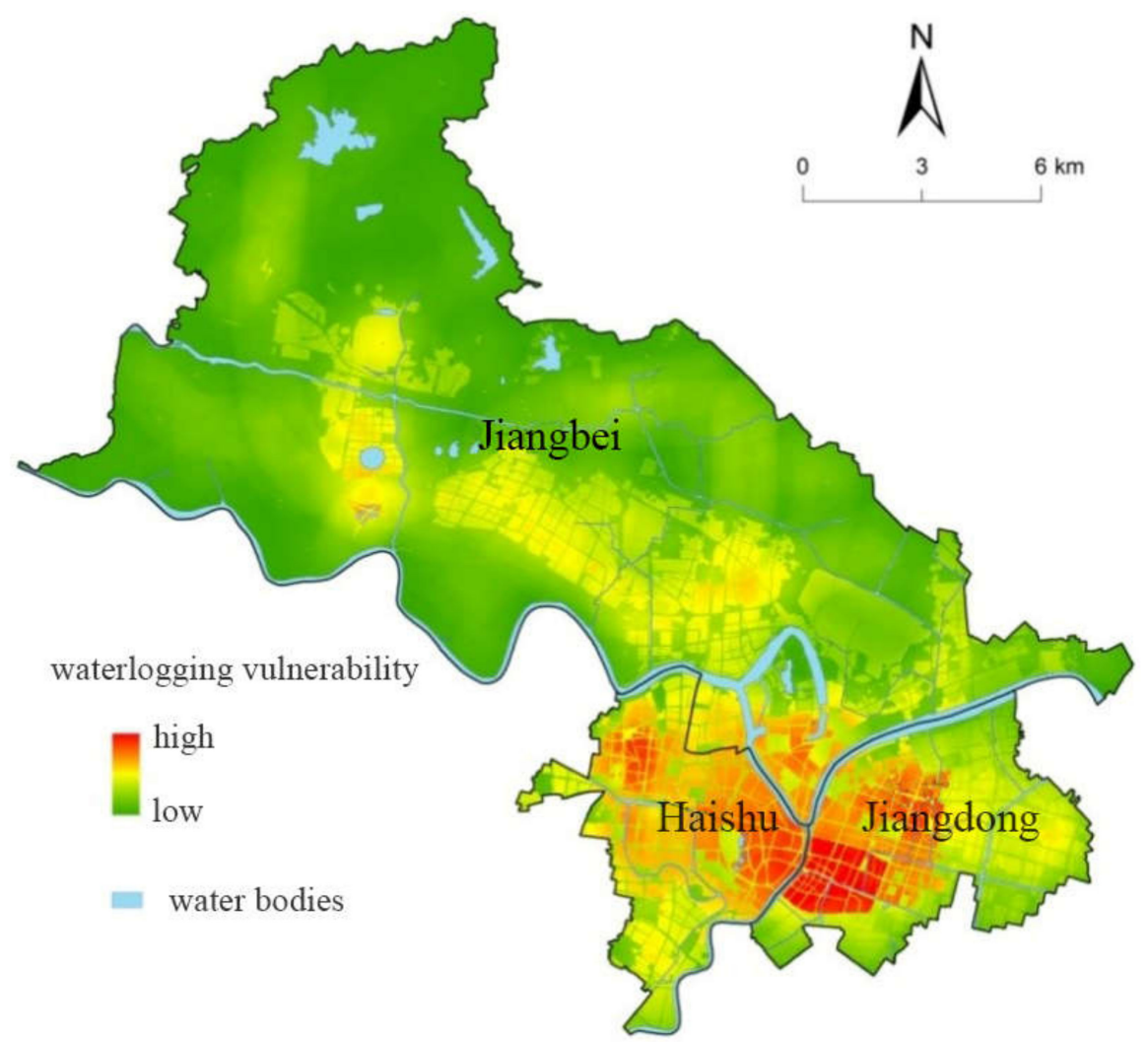

Figure 11. Waterlogging vulnerability distribution map in the city proper of Ningbo.

The statistics at different grades in waterlogging risk areas show that the total area with low waterlogging risk in the city proper of Ningbo is $100.3 \mathrm{~km}^{2}$, accounting for $36.9 \%$. The medium-risk area was equal to the higher-risk area, both at a total of $50.7 \mathrm{~km}^{2}$, accounting for $18.7 \%$. This was followed by the lower-risk area, accounting for $15.5 \%$, and the high-risk area, accounting for $9.6 \%$.

\subsubsection{Verification}

The data of water accumulation points in the city proper of Ningbo were mainly collected through field surveys and reports from various news resources, and included 114 water accumulation points. Using ArcGIS 10.2, this study spatialized the information of stagnant water points on the basis of place names and coordinate values and verified the waterlogging disaster of the city proper of Ningbo through superimposing the results on the waterlogging risk zoning map. Figures 12 and 13 shows that the distribution of stagnant water points in the city proper of Ningbo is consistent with the trend of the risk-level change of assessment results. According to statistics, $80.1 \%$ of the collected water points are located in high-risk and higher-risk areas, $12.1 \%$ are located in the medium risk areas, and the remaining $7.8 \%$ are located in low-risk and lower-risk areas. Comparing the waterlogging points in the city proper of Ningbo with the zoning map of waterlogging risk assessment, the result shows that the evaluation is consistent with the actual situation, and it also proves the rationality of the risk assessment model. 


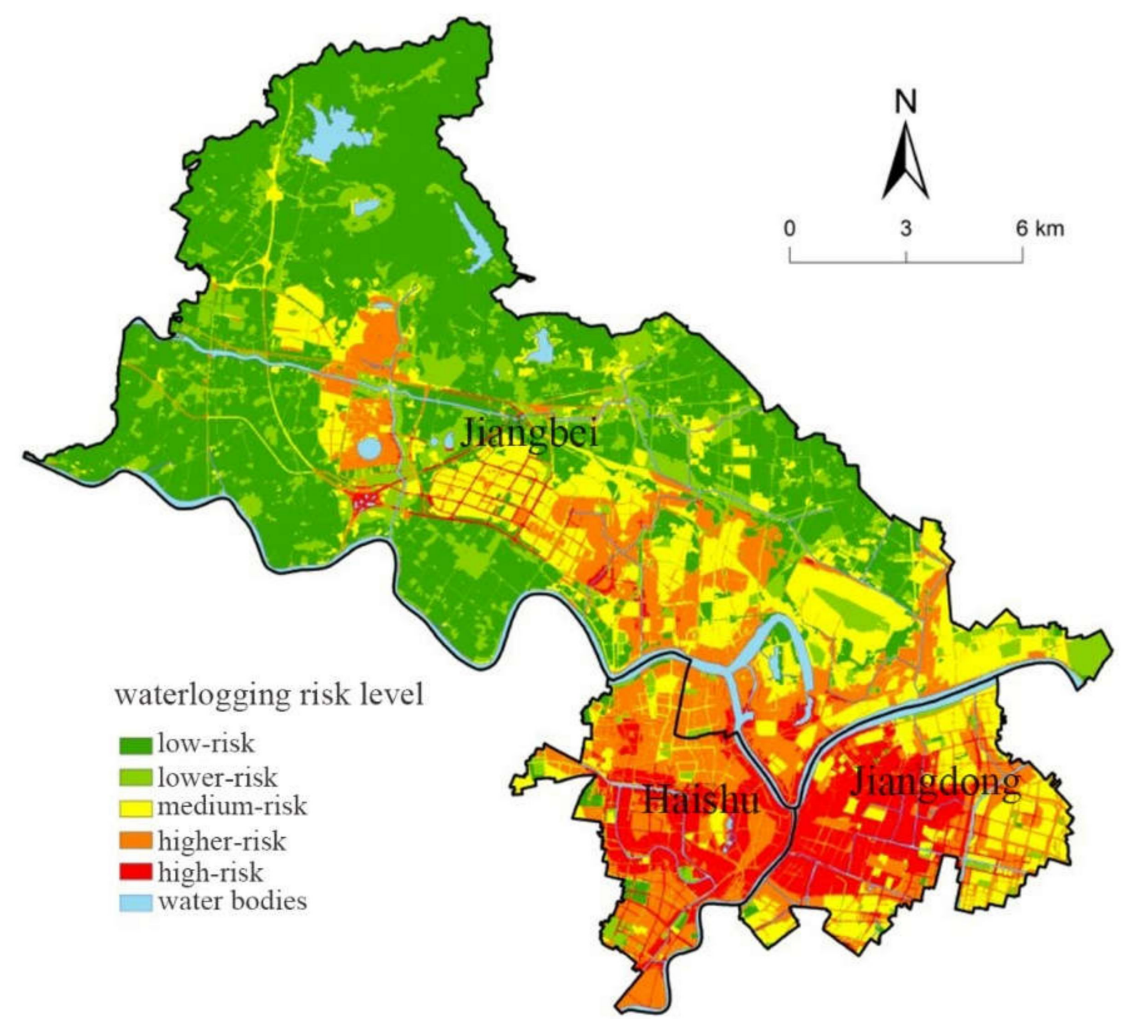

Figure 12. The zoning map of waterlogging risk assessment in the city proper of Ningbo.

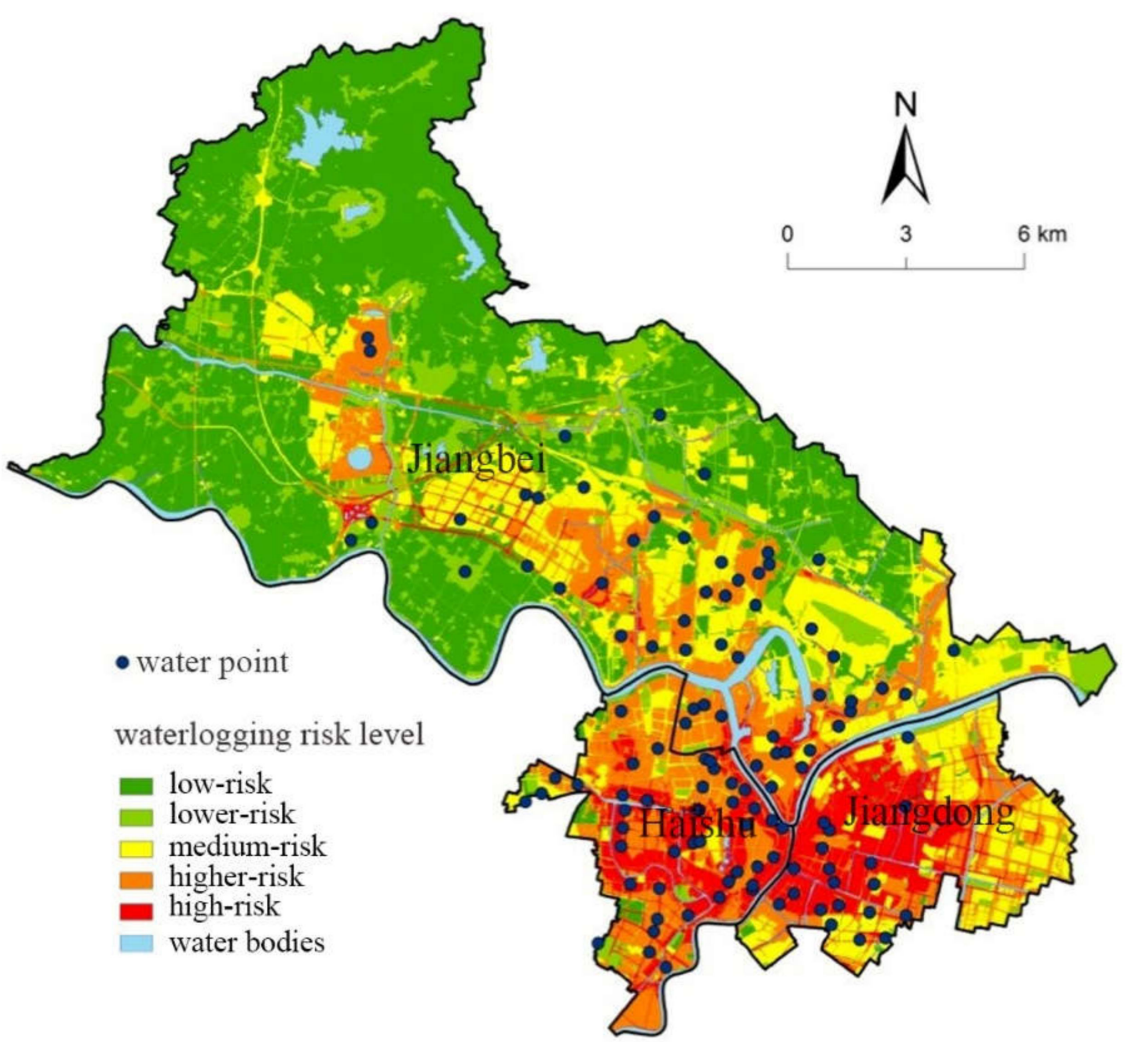

Figure 13. Comparison with waterlogging water points in the city proper of Ningbo and risk assessment results. 


\section{Discussion}

Urban waterlogging disasters have become the main type of disasters in Chinese cities, seriously affecting the economic development, especially in coastal areas. Based on the theory of natural disaster risk, this study carried out a waterlogging risk assessment and then analyzed spatial distribution characteristics by taking the example of the city proper of Ningbo. The main conclusions are summarized as follows.

(1) By considering the small watershed as the research unit, this study conducted the risk assessment of city proper of Ningbo with different grades of waterlogging by combining with the SCS-CN model and superimposing the risk assessment map. The results show that the low-risk areas were mainly located in Jiangbei district, and the high-risk areas were mainly located in the middle of Jiangdong district and the southern part of Haishu district. The dangerousness for waterlogging factors in the city proper was mainly low.

(2) On the basis of the weight coefficients, this study superimposed the secondary index layer of disaster-prone environment sensitivity to obtain the assessment map of disaster-prone environment sensitivity in the city proper of Ningbo. The results show that the areas with low sensitivity were mainly located in the northern part of Jiangbei district, and the areas with medium-high sensitivity were located in the southern part of the city proper. The distribution of the highly sensitive area was largely affected by the river networks because the type of land cover affects the distribution pattern of urban waterlogging sensitivity.

(3) On the basis of the weight coefficients, this study obtained the assessment map of waterlogging vulnerability in the city proper of Ningbo by overlaying the population density and road density layers. The results showed that the areas with low vulnerability were mainly located in Jiangbei district; the areas with high vulnerability were mainly located at the intersection of three rivers, namely, Jiangdong district, Haishu district, and Jiangbei district; and small parts of this area was located in Wangchun street, Haishu district.

(4) On the basis of the weight coefficients, this study obtained the waterlogging risk assessment map in the city proper of Ningbo by overlaying three first-level index layers. The results showed that the low-risk area was mainly located in the northern part of Jiangbei district, the higher-risk area was mainly located in Haishu district, with small parts located in the middle of Jiangbei district, and the high-risk areas were mainly concentrated in the west of Jiangdong district and the middle of Haishu district. In general, the eastern part of Jiangdong district and Haishu district of Ningbo were areas with a high incidence of waterlogging.

\section{Conclusions}

China has witnessed frequent extreme rainfall events because of the continuous intensification of global warming and the rapid development of urbanization. Although many studies have investigated urban waterlogging on the basis of different views, few studies have proposed a comprehensive risk assessment model to help mitigate urban waterlogging risk. Urban waterlogging risk assessments are an effective way to reduce socio-economic loss, and perfecting existing risk assessment methods could help public sectors better prevent urban waterlogging. Therefore, this study evaluated urban waterlogging from the perspectives of dangerousness, sensitivity, and vulnerability, and further optimized the waterlogging disaster risk assessment model by increasing pumping station flow and road density indicators and increasing the weight of waterlogging risk, which provides a new way in the field of urban waterlogging risk assessment. Moreover, this study also conducted a case study of the city proper of Ningbo to assess waterlogging, which provides theoretical significance for the development of flood control in coastal cities.

However, this study was not without certain limitations. Firstly, although this paper proposes an alternative risk assessment model, some other factors that may affect risk 
assessment of urban waterlogging were not discussed in this study. With regard to the loss caused by urban waterlogging disasters, reasonable and orderly disaster assistance activities can enhance the ability to deal with disasters and reduce the risk level. In this paper, human factors including urban monitoring and early warning ability, medical treatment, and residents' self-rescue abilities were less considered in the process of the model construction. Therefore, it is necessary to consider the loss caused by waterlogging disasters and the disaster prevention mechanisms of residents and relevant government departments in a future study, which could improve urban waterlogging risk assessment models in coastal cities. Secondly, this study only considered urban waterlogging in the city proper of Ningbo. This means that the empirical results may not be generalizable and representative of all cities in China. Therefore, subsequent studies should be carried out to further explore other factors that may affect urban waterlogging. Additionally, future study should be extended to different cities in China, thereby helping government agencies design appropriate polices. Finally, further research can consider designing experiments to simulate real urban waterlogging, which could be more consistent with real events.

Author Contributions: Conceptualization, M.Z., X.W. and K.L.; data curation, M.Z. and C.Z.; formal analysis, X.F., K.L. and L.X.; investigation, K.L. and C.Z.; methodology, M.Z. and L.X.; project administration, X.W. and X.F.; software, K.L., C.Z. and L.X.; supervision, X.W. and X.F.; validation, M.Z. and K.L.; writing-original draft, M.Z., X.F. and C.Z.; writing-review and editing, X.W. and X.F. All authors have read and agreed to the published version of the manuscript.

Funding: This research received no external funding.

Data Availability Statement: Not applicable.

Conflicts of Interest: The authors declare no conflict of interest.

$\begin{array}{ll}\text { Abbreviations } \\ \text { ILLUDAS } & \text { Illinois Urban Drainage Area Simulator } \\ \text { SRM } & \text { Snowmelt-Runoff Model } \\ \text { SWMM } & \text { Storm Water Management Model } \\ \text { GDP } & \text { Gross Domestic Product } \\ \text { DEM } & \text { Digital Elevation Model } \\ \text { SCS-CN } & \text { Soil Conservation Service Curve Number } \\ \text { AHP } & \text { Analytic Hierarchy Process }\end{array}$

\section{References}

1. Jenkins, K.; Surminski, S.; Hall, J.; Crick, F. Assessing surface water flood risk and management strategies under future climate change: Insights from an Agent-Based Model. Sci. Total Environ. 2017, 595, 159-168. [CrossRef]

2. Gupta, V.; Jain, M.K. Impact of ENSO, global warming, and land surface elevation on extreme precipitation in India. J. Hydrol. Eng. 2020, 25, 05019032. [CrossRef]

3. Wang, Y.J.; Gao, C.; Zhai, J.Q.; Li, X.C.; Su, B.D.; Hartmann, H. Spatio-temporal changes of exposure and vulnerability to floods in China. Adv. Clim. Chang. Res. 2014, 5, 197-205. [CrossRef]

4. Menéndez, M.; Woodworth, P.L. Changes in extreme high water levels based on a quasi-global tide-gauge data set. J. Geophys. Res. Ocean. 2010, 115. [CrossRef]

5. Xia, J.; Zhang, Y.Y.; Xiong, L.H.; He, S.; Wang, L.F.; Yu, Z.B. Opportunities and challenges of the Sponge City construction related to urban water issues in China. Sci. China Earth Sci. 2017, 60, 652-658. [CrossRef]

6. Ministry of Water Resources of the People's Republic of China. China Flood and Drought Disaster Bulletin 2018; China Water Resources Press: Beijing, China, 2019; pp. 15-32. (In Chinese)

7. Alderman, K.; Turner, L.R.; Tong, S. Floods and human health: A systematic review. Environ. Int. 2012, 47, 37-47. [CrossRef]

8. Ministry of Housing and Urban-Rural Development of The People's Republic of China. Code for Design of Outdoor Wastewater Engineering 2011; Ministry of Housing and Urban-Rural Development of the People's Republic of China (MOHURD): Beijing, China; General Administration of Quality Supervision, Inspection and Quarantine of the People's Republic of China: Beijing, China, 2011. (In Chinese)

9. Zhang, Q.; Wu, Z.; Zhang, H.; Fontana, G.D.; Tarolli, P. Identifying dominant factors of waterlogging events in metropolitan coastal cities: The case study of Guangzhou, China. J. Environ. Manag. 2020, 271, 110951. [CrossRef] 
10. Zhang, H.; Cheng, J.; Wu, Z.; Cheng, L.; Qin, J.; Liu, T. Effects of impervious surface on the spatial distribution of urban waterlogging risk spots at multiple scales in Guangzhou, South China. Sustainability 2018, 10, 1589. [CrossRef]

11. Yu, H.; Zhao, Y.; Fu, Y.; Li, L. Spatiotemporal Variance Assessment of Urban Rainstorm Waterlogging Affected by Impervious Surface Expansion: A Case Study of Guangzhou, China. Sustainability 2018, 10, 3761. [CrossRef]

12. Quan, R.S.; Liu, M.; Lu, M.; Zhang, L.J.; Wang, J.J.; Xu, S.Y. Waterlogging risk assessment based on land use/cover change: A case study in Pudong New Area, Shanghai. Environ. Earth Sci. 2010, 61, 1113-1121. [CrossRef]

13. Eagleson, P.S. Dnamic Hydrology; Mc Graw-Hill Book Company: New York, NY, USA, 1970.

14. Keifei, C.J.; Huang, C.Y.; Wolka, K. Modified Chicago Hydrograph method, Storm Sewer Design; University of Illionis: Chicago, IL, USA, 1978.

15. USDA-SCS. Hydrology. In National Engineering Handbook; Section 4; Soil Conservation Service, US Department of Agriculture: Washington, DC, USA, 1985.

16. Rauch, W.; Bertrand-Krajewski, J.L.; Krebs, P.; Mark, O.; Schilling, W.; Schütze, M.; Vanrolleghem, P.A. Deterministic modelling of integrated urban drainage systems. Water Sci. Technol. 2002, 45, 81-94. [CrossRef] [PubMed]

17. Salarpour, M.; Rahman, N.A.; Yusop, Z. Simulation of flood extent mapping by InfoWorks RS-Case study for tropical catchment. J. Softw. Eng. 2011, 5, 127-135. [CrossRef]

18. Scofield, R.A. The NESDIS operational convective precipitation-estimation technique. Mon. Weather Rev. 1987, 115, 1773-1793. [CrossRef]

19. Bisht, D.S.; Chatterjee, C.; Kalakoti, S.; Upadhyay, P.; Sahoo, M.; Panda, A. Modeling urban floods and drainage using SWMM and MIKE URBAN: A case study. Nat. Hazards 2016, 84, 749-776. [CrossRef]

20. Xu, S.Y.; Wang, J.; Shi, C. Research of the natural disaster risk on coastal cities. Acta Geogr. Sin. 2006, 61, 127-138. (In Chinese)

21. Peng, Y. A comparison of two approaches to develop concentrated rural settlements after the 5.12 Sichuan Earthquake in China. Habitat Int. 2015, 49, 230-242. [CrossRef]

22. Peng, Y.; Zhu, X.T.; Zhang, F.Y.; Huang, L.; Xue, J.B.; Xu, Y.L. Farmers' risk perception of concentrated rural settlement development after the 5.12 Sichuan Earthquake. Habitat Int. 2018, 71, 169-176. [CrossRef]

23. Cui, P.; Li, D.Z. Measuring the disaster resilience of an urban community using ANP-FCE method from the perspective of capitals. Soc. Sci. Q. 2019, 100, 2059-2077. [CrossRef]

24. Shi, Y. Risk analysis of rainstorm waterlogging on residences in Shanghai based on scenario simulation. Nat. Hazards 2012, 62, 677-689. [CrossRef]

25. Quan, R.S.; Zhang, L.J.; Liu, M.; Lu, M.; Wang, J.J.; Niu, H.Y. Risk assessment of rainstorm waterlogging on subway in central urban area of Shanghai, China based on scenario simulation. In Proceedings of the 19th International Conference on Geoinformatics, Shanghai, China, 24-26 June 2011; pp. 1-6.

26. Huang, H.B.; Chen, X.; Zhu, Z.Q.; Xie, Y.H.; Liu, L.; Wang, X.W.; Wang, X.; Liu, K. The changing pattern of urban flooding in Guangzhou, China. Sci. Total Environ. 2018, 622, 394-401. [CrossRef]

27. Wang, X.N.; Wang, X.W.; Zhai, J.Q.; Li, X.C.; Huang, H.B.; Li, C.M.; Zheng, J.; Sun, H.Y. Improvement to flooding risk assessment of storm surges by residual interpolation in the coastal areas of Guangdong Province, China. Quat. Int. 2017, 453, 1-14. [CrossRef]

28. Zhang, J.Y.; Chen, Y.B. Risk assessment of flood disaster induced by typhoon rainstorms in Guangdong province, China. Sustainability 2019, 11, 2738. [CrossRef]

29. Zhang, H.P.; Cheng, X.W.; Jin, L.; Zhao, D.; Feng, T.J.; Zheng, K. A Method for Estimating Urban Flood-Carrying Capacity Using the VIS-W Underlying Surface Model: A Case Study from Wuhan, China. Water 2019, 11, 2345. [CrossRef]

30. Liu, Q.; Yang, H.M.; Liu, M.; Sun, R.; Zhang, J.H. An Integrated Flood Risk Assessment Model for Cities Located in the Transitional Zone between Taihang Mountains and North China Plain: A Case Study in Shijiazhuang, Hebei, China. Atmosphere 2019, 10, 104. [CrossRef]

31. Wu, Z.N.; Shen, Y.X.; Wang, H.L. Assessing urban areas' vulnerability to flood disaster based on text data: A case study in Zhengzhou city. Sustainability 2019, 11, 4548. [CrossRef]

32. Su, B.N.; Huang, H.; Zhang, N. Dynamic urban waterlogging risk assessment method based on scenario simulations. J. Tsinghua Univ. (Sci. Technol.) 2015, 55, 684-690. (In Chinese)

33. Huang, T.L.; Wang, Y.P. Assessment of Waterlogging Hazard in Tianhe District of Guangzhou City Using Remote Sensing and GIS. In Proceedings of the 19th International Conference on Geoinformatics, Shanghai, China, 24-26 June 2011.

34. Pandey, A.C.; Singh, S.K.; Nathawat, M.S. Waterlogging and flood hazards vulnerability and risk assessment in Indo Gangetic plain. Nat. Hazards 2010, 55, 273-289. [CrossRef]

35. Gao, B.; Zhao, X.H.; Sun, X.; Peng, C.R. Study on risk assessment of urban waterlogging. In 2009 Third international symposium on intelligent information technology application. IEEE 2009, 3, 352-355.

36. Schmitt, T.G.; Thomas, M.; Ettrich, N. Analysis and modeling of flooding in urban drainage systems. J. Hydrol. 2004, 299, 300-311. [CrossRef]

37. Benito, G.; Lang, M.; Barriendos, M.; Llasat, M.C.; Francés, F.; Ouarda, T.; Thorndycraft, V.; Enzel, Y.; Bardossy, A.; Coeur, D.; et al. Use of systematic, palaeoflood and historical data for the improvement of flood risk estimation. Review of scientific methods. Nat. Hazards 2004, 31, 623-643.

38. Kaźmierczak, A.; Cavan, G. Surface water flooding risk to urban communities: Analysis of vulnerability, hazard and exposure. Landsc. Urban Plan. 2011, 103, 185-197. [CrossRef] 
39. Zhang, M.S.; Tang, Y.M. Risk investigation method and practice of geohazards. Geol. Bull. China 2008, 27, 1205-1216. (In Chinese)

40. Liu, Y.H.; Ge, Q.S.; Wu, W.X. Risk Management: Challenges of the New Century; China Meteorological Press: Beijing, China, 2005. (In Chinese)

41. Xu, J.W.; Zhang, M.S.; Fan, W. An overview of geological disaster risk assessment. J. Catastrophology 2015, 30, 130-134. (in Chinese).

42. Maskrey, A. Disaster Mitigation: A Community based Approach; Oxfam: Oxford, UK, 1989.

43. United Nations Department of Humanitarian Affairs (UNDHA). Mitigating Natural Disasters: Phenomena, Effects and Options: A Manual for Policy Makers and Planners; United Nations: New York, NY, USA, 1991.

44. Okada, N. Urban diagnosis and integrated disaster risk management. J. Nat. Disaster Sci. 2004, 26, 49-54.

45. Shi, P.J. Theory on disaster science and disaster dynamics. J. Nat. Disasters 2002, 3, 1-9. (In Chinese)

46. Zhang, Q.N.; Li, N. The Quantitative Method and Its Application of Risk Assessment and Management of Major Meteorological Disasters; Beijing Normal University Press: Beijing, China, 2007. (In Chinese)

47. Lin, T.; Liu, X.F.; Song, J.C.; Zhang, G.Q.; Jia, Y.Q.; Tu, Z.Z.; Liu, C.L. Urban waterlogging risk assessment based on internet open data: A case study in China. Habitat Int. 2018, 71, 88-96. [CrossRef]

48. Sun, S.; Zhai, J.Q.; Li, Y.; Huang, D.P.; Wang, G.F. Urban waterlogging risk assessment in well-developed region of Eastern China. Phys. Chem. Earth Parts A/B/C 2020, 115, 102824. [CrossRef]

49. Saaty, T.L. The Analytic Hierarchy Process; McGraw-Hill: New York, NY, USA, 1980.

50. Huang, T.L.; Zhang, J.L.; Wang, Y.P. Simulation and analysis of urban waterlogging in Liwan district, Guangzhou city. Pearl River 2015, 36, 135-138. (In Chinese)

51. Zhu, X.C.; Gao, Y.; Gao, J.Q. GIS-Based risk assessment method for county-level administrative regions: A case Study of rainstorm and flood disasters. Trop. Geogr. 2014, 34, 704-711. (In Chinese)

52. Peng, Y.; Gu, X.B.; Zhu, X.T.; Zhang, F.Y.; Song, Y. Recovery evaluation of villages reconstructed with concentrated rural settlement after the Wenchuan earthquake. Nat. Hazards 2020, 104, 139-166. [CrossRef]

53. Gao, W.Y.; Li, M.; Li, J. Distribution characteristics of waterlogging in Xi'an and its relationship with precipitation. J. Shaanxi Meteorol. 2014, 2, 17-20. (In Chinese) 